\title{
KONSEP KAFIR PERSPEKTIF IZZAT DARWAZAH DAN IMPLIKASINYA PADA REALITAS KEKINIAN
}

\author{
Rudy al Hana \\ Universitas Islam Negeri Sunan Ampel Surabaya, Indonesia \\ E-mail: rudialhana@yahoo.co.id
}

\begin{abstract}
The word kaffir is always interesting to be interpreted. Basically, this word is used by the Qur'ān to mention the unbelievers of Allah and who are hostile to Muslims in the process of Islamic da'wah. But this article will describe the use of the word kaffir in the contemporary era. Is it still relevant to be mentioned for the unbeliever of Allah? Dose it has another interpretation term in real life and evident? To answer these questions, Izzat Darwazah's view on keafir in the Qur'ān, i.e., al-Kāfirūn will be conducted as a model of interpretation. This article finds that the word kafir, officially, cannot be removed from the Qur'ān and intellectual discourse. However, it will not be relevant to call the unbeliever as kaffir. Yet, the common word used in the democratic era is non-Muslim. This word also will eliminate the barrier between Muslim and the unbeliever in a plural society; and as linguistic analysis, more compatible than kajfir which had metaphor meaning.
\end{abstract}

Keywords: Käfir; tafsīr nuzūlī; Izzat Darwazah.

\section{Pendahuluan}

Kata "kafir" (käfir) dalam al-Qur'ān disebut sebanyak 525 kali, yang dalam pandangan para pakar tafsir, masing-masing memiliki konteks yang berbeda-beda. Ada kalanya, kata tersebut menunjukkan konteks celaan atau caci-maki. Celaan tersebut ditujukan kepada orang yang menutup atau kufur nikmat. Ia tidak bersyukur dan enggan melakukan kebaikan. Di antara surat yang berbicara tentang hal itu adalah al-Zukhruf [43]: 15, Saba' [34]: 13, Ibrāhīm

\footnotetext{
${ }^{1}$ Muḥammad Fu'ād 'Abd al-Bāqī, Mu'jam al-Mufahras li Alfāz al-Qur'àn al-Karìm (Kairo: Dār Kutub al-Mișrīyah, 1364), 714-720.
} 
[14]: 7, dan lainnya. ${ }^{2}$ Ada pula yang berkonteks kondisi sosial masyarakat tertentu, yang memiliki sikap atau sifat tidak seperti yang diajarkan di dalam Islam, seperti menutupi atau kufur (kufr) terhadap nikmat-nikmat yang diberikan oleh Allah dalam kehidupan mereka sehari-hari. ${ }^{3}$

Kendati sebutan kafir sudah masyhur dan mafhum dalam konteks keagamaan, penyebutan kata ini harus tetap disandarkan pada konteks-konteks tertentu. Nabi, para sahabat, dan ulama salaf memberikan koridor pelabelan (labelling) kafir dengan sangat hatihati. Tidak semua orang (yang tidak mengakui keberadaan keyakinan umat Islam) dapat dituduh sebagai kafir dan diperangi seperti pada era penyebaran Islam. Nabi bersabda, "barang siapa yang menuduh seseorang sebagai kafir atau musuh Allah, tapi ungkapan tersebut tidak terbukti, maka tuduhan itu kembali pada dirinya". ${ }^{4}$ Dengan demikian, Nabi dan para ulama tidak menganjurkan umat Islam menvonis orang lain sebagai kafir, kecuali hal itu bisa dibuktikan dengan pelbagai alasan yang kuat.

Problem masyarakat Islam di era kontemporer adalah mereka sudah tidak memiliki otoritas tunggal seperti yang terjadi pada masa Nabi Muḥammad ketika masih hidup. Dampaknya, penyebutan kafir bermetamorfosa menjadi paradigma teososiologis, bahkan bisa dibawa ke ranah politik. Bahkan, sejarah menunjukkan, hal tersebut mulai terlihat tidak lama pascawafatnya Nabi, tepatnya ketika kelompok teologi Khawārij menyatakan kafir lawan politiknya (dalam hal ini terutama kelompok Shi'sh), ataupun sebaliknya. ${ }^{5}$ Kondisi masa klasik Islam tersebut tampaknya tidak sekompleks kondisi saat ini, di mana terminologi kafir mulai digunakan dalam kondisi dan dengan cara yang beragam. Bahkan, saat ini ada kelompok Islam yang masih merasa menjadi jajahan "non-Muslim", dan menggunakan sebutan kafir sebagai labelling

\footnotetext{
2 Al-Rāghib al-Aṣfahānī, Mufradāt Alfāẓ al-Qurāan, Vol. 4 (Damaskus: Dār Qalam, 2009), 714.

${ }^{3}$ Mat Jalil, "Falsafah Hakikat Iman, Islam dan Kufur", Ath-Thariq: Jurnal Dakwah dan Komunikasi, Vol. 2, No. 2 (2019), 389.

4 “Tentang Non-Muslim bukan Kafir", 2 Maret 2019, https://www.nu.or.id/ post/read/103224/tentang-non-muslim-bukan-kafir. Diakses 22 November 2019.

${ }^{5}$ Harun Nasution, Teologi Islam: Aliran-aliran Sejarah Analisa Perbandingan (Jakarta: UI Press, 2011), 35.
} 
bagi musuh Islam. $^{6}$ Mereka, misalnya, menyebut orang-orang Amerika sebagai kafir.

Di Indonesia, problem penggunaan istilah kafir lebih kompleks dibanding apa yang pernah ada dalam lintasan sejarah Islam. Ragam kejadian di Indonesia mengindikasikan bahwa penyebutan kafir sudah tidak dapat dispesifikkan pada kondisi dan situasi tertentu. Leksikologi kata kafir sering kali dinyatakan kepada kelompok non-Muslim yang memang secara akidah berbeda dengan umat Islam. Penyebutan kafir juga digunakan pada mereka yang berbeda pandangan secara teologi Islam. Bahkan, hanya karena persinggungan persoalan pribadi, kata kafir bisa dinyatakan untuk menggugah emosi publik baik dari sisi keagamaan maupun sosial-politik.

Terlepas dari pelbagai ragam diskursus penyebutan kata kafir di atas, artikel ini bertujuan mengembalikan kata kafir berdasarkan kaidah atau metode tafsir yang disepakati oleh para ulama. Tidak hanya kata kafir yang dinarasikan dalam rujukan-rujukan akademik, artikel ini juga meninjau ulang pandangan ulama Indonesia terkait diskursus tersebut di ruang demokrasi Indonesia. Untuk kepentingan itu, artikel ini akan mengeksplorasi pandangan Izzat Darwazah terkait kata kafir, khususnya yang ia paparkan dalam surat al-Kāfirūn [109]; bagaimana konteks pemaknaan berdasarkan metode asbāb al-nuzūl yang menjadi ke-khas-an pemikiran Darwazah; dan bagaimana sikap yang ideal menurut Darwazah apabila bertemu dengan orang kafir dalam konteks kekinian.

Kajian ini dilakukan menurut kerangka paradigma sosiolinguistik. ${ }^{7}$ Kerangka ini dipakai untuk membantu menyimpulkan tentang kesesuaian penggunaan kata kafir dengan kondisi sosial yang ada di Indonesia; kemungkinan adanya kosa kata berbeda yang lebih diterima dari pada kafir; dan bagaimana posisi teks alQur'ān harus diinterpretasikan dalam kondisi sosial masyarakat kontemporer.

${ }^{6}$ Muhammad 'Izzah Darwazah, Tafsì al-Hadith Tartīb al-Suwar Hasb al-Nuzül, Vol. 2 (Kairo: Dār al-Gharb al-Islāmī, 2000), 106.

7 Abdul Mustaqim, Dinamika Sejarah Tafsir al-Qur'an (Yogyakarta: Adab Press, 2014), 113. 


\section{Izzat Darwazah: Biografi dan Corak Penafsirannya}

Nama lengkap Darwazah adalah Muhammad 'Izzah b. 'Abd alHādī b. Darwīsh b. Ibrāhīm b. Hasan Darwazah. ${ }^{8}$ Ia lahir pada hari sabtu, 11 Syawal 1305 H/ Juni 1887 M di Kota Neblus, Palestina. Nama Darwazah merupakan nama keluarga yang telah digunakan secara turun temurun. Kata Darwazah berasal dari bahasa Arab daräzah, yang berarti khiyätah atau penjahit. Diberi nama tersebut karena sebagian besar keluarganya berprofesi sebagai penjahit.' Pada usia 5 tahun, Darwazah belajar membaca, menulis, dan tajwid al-Qur'ān. Pada usianya yang ke-12, setelah meraih ijazah tingkat dasar yang ditempuhnya, Darwazah melanjutkan studinya ke Thānawìah (i'dāed) di Madrasah al-Rushdīyah dan lulus pada 1905. Saat itu, Thānawìah merupakan jenjang lembaga pendidikan tertinggi yang ada di kota Neblus. ${ }^{10}$

Darwazah melanjutkan studinya ke Istanbul dan Beirut. Ia lebih memilih belajar ototidak dari pada harus melanjutkan ke sekolah formal. Hal tersebut disebabkan oleh faktor ekonomi yang membatasinya sehingga tidak bisa terus belajar di sekolah-sekolah formal. Namun, karena semangatnya yang tidak pupus, banyak buku yang dipelajari dan ditelaahnya yang berkaitan dengan gramatika bahasa Arab, sastra, sejarah, ilmu sosial, filsafat, hadīth, fiqh, dan kalam. Selain buku-buku berbahasa Arab, ia juga rajin membaca buku-buku berbahasa Turki dan bahasa lainnya dengan berbagai tema. Darwazah sempat mendatangi beberapa ulama untuk mempelajari ilmu-ilmu agama. Ia belajar fiqh kepada Shaykh Muștafā al-Khiyāt di Nablus, hadīth kepada Shaykh Sulaymān alShurabī, serta nạ̣wu dan șarf kepada Shaykh Mūsā al-Qudumī.

Selain itu, ia juga membaca artikel-artikel yang ditulis oleh Muḥammad 'Abduh, Rashīd Rị̣ā, Musțafā Șādiq al-Rāfíī, dan Qāsim Amīn. Darwazah hidup saat Palestina mengalami goncangan politik dengan meniti transisi kekuasaan yang berbedabeda. Dimulai ketika Palestina berada dalam kekuasaan Turki 'Uthmānī yang pada 1917 beralih kepada anak revolusi industri yaitu Inggris, hingga konflik berdarah dengan Israel mulai 1938

\footnotetext{
${ }^{8}$ Muhammad 'Alī Iyāzī, al-Mufassirūn Hayātubum wa Manhajubum (t.t.: al-Thaqāfah al-Irshād al-Islāmī, t.th.), 453.

${ }^{9}$ Darwazah, Tafsir al-Hadith, Vol. 10, 23.

${ }^{10}$ Ibid., 23.
} 
sampai sekarang dalam memperebutkan kedaulatan masingmasing. ${ }^{11}$ Dinamika politik yang dialami Darwazah memiliki pengaruh signifikan pada produk penafsiran ayat al-Qur'ān yang dihasilkannya. Darwazah aktif di organisasi dan menjabat sebagai Anggota Sekretaris pada Majelis Ilmu di Neblus (1911), Anggota Pemuda Suriah (1916), Anggota Sekretaris Jenderal al-Fatat (19191920), Anggota Perkumpulan Kebangsaan (1919), Sekretaris Kongres Arab-Palestina di Qudus (1921-1932), dan Anggota Militer di Damaskus (1919-1920). ${ }^{12}$

Secara ideologis, Darwazah menjadi nasionalis-Arab yang mendukung kesatuan negara Arab-Syria raya. Pengalamannya di Damaskus membuktikan bahwa universalitas nasionalisme Arab tidak sekongkret yang ia bayangkan dan bahwa ada keinginan khusus politik lokal. Kemudian setelah raja Faisal dipecat di Prancis, Darwazah kembali ke Nablus dan aktif dalam perjuangan nasional Palestina yang selama periode kekuasaan Inggris (19221948) terpisah dari gerakan umum nasionalisme Arab. Bagi Darwazah, konstituen utama nasionalisme Arab adalah mereka yang berbahasa Arab, penduduk pribumi Arab, serta memiliki sejarah dan kepentingan yang sama. ${ }^{13}$

Konflik politik yang terjadi saat itu menyebabkan Darwazah masuk rumah tahanan. Akibatnya, ia berhenti dalam aktivitas politik yang digelutinya. Selama dalam rumah tahanan tersebut, Darwazah berhasil menyelesaikan tiga karya tafsirnya dalam bentuk tafsì nuzūlì mawdǚr (tematik sesuai dengan turunnya ayat). Ketiga karya tafsir yang berbicara tentang kenabian Muhammad ini adalah 'Ashr al-Nabi wa Bi'atuh Qabl al-Bi'thab: Suwar al-Muqtabasah min alQur'àn al-Karim wa Dirāsāt wa Taḅlìlàt Qur'ānìyah, Sirat al-Rasūl: Suwar Muqtasabah wa Taḥlilāt wa Dirāsāt Qur'ānìyah, dan al-Dustūr alQur'änyah wa al-Sunnah al-Nabawiyah fì Shu'ün al-Hayät al-Nabawìyah.

Berkecamuknya politik saat itu tidak sedikitpun mempengaruhinya untuk terus berkarya. Meskipun saat itu masih diasingkan di Turki dan tidak diperkenankan untuk kembali ke Palestina, Darwazah justru menambah dua lagi deretan karyanya, yaitu alQur'ān al-Majid dan al-Tafsì al-Hadith. Karya yang pertama

${ }^{11}$ Ibid., 26.

12 Ibid., 25.

13 Muhammad 'Izzah Darwazah, Nash'at al-Harakah al-'Arabiyah al-Hadithah, Vol. 2 (t.t.: Sidon, 1971), 38-39. 
merupakan pengantar dari karya yang kedua. Sementara karya yang kedua merupakan karya tafsir al-Qur'ān 30 juz dengan tetap menggunakan metode nuzūlī (sesuai turunnya ayat). Di sisi lain, Darwazah telah menulis 22 karya di bidang sejarah, sembilan di bidang al-Qur'ān dan tafsir, empat di bidang pendidikan, satu di bidang hadīth, dan beberapa artikel khusus mengenai sejarah Palestina. Darwazah pada akhirnya juga terkenal sebagai ahli sejarah karena kefokusannya dalam menekuni bidang tersebut.

Darwazah meninggal dunia pada 1984 di Damaskus di usia 96 tahun. Ia memiliki tiga putri yang bernama Najāh, Salmā, Rudaynā, serta seorang putra bernama Zuhayr. Keempat anaknya ini ia peroleh dari pernikahan pertamanya dengan putri pamannya yang bernama Fāṭimah b. Qāsim Darwazah. Pada 1938, Fāțimah meninggal dunia di Damaskus. Darwazah pun menikah untuk yang kedua kalinya pada 1946 dengan Layqah b. Ānīs al-Tamīmī. Namun, pernikahan yang kedua ini tidak dikaruniai anak. Pada 1975, Layqah meninggal dunia di Damaskus. ${ }^{14}$

\section{Metodologi Penafsiran Darwazah}

Setelah kajian autobiografi di atas, perlu dipaparkan tentang metodologi dan corak yang dikembangkan Darwazah dalam menafsirkan al-Qur'ān (dalam kitab al-Tafsìr al-Hadith). Dalam menafsirkan al-Qur'ān, Darwazah menggunakan metode tartīb alnuzüli, di mana bentuk penafsiran disesuaikan dengan urutan turunnya ayat). Ia menafsirkan dengan mengurutkan surat yang pertama kali turun. Tartib al-nuzūl (urutan turunnya ayat) yang digunakan Darwazah merupakan urutan surat yang dicetuskan oleh Muhammad Ogly, di mana surat yang diletakkan pertama adalah al-Fātiḥah, lalu al-'Alaq, al-Qalam, al-Muzzammil sampai surat terakhir yang diturunkan di Mekah (Makkiyah), kemudian disusul oleh surat yagn diturunkan di Madinah (Madaniyab) yaitu alBaqarah, al-Anfāl, dan seterusnya.

Tartīb al-suwar (urutan turunnya surat) atau tartīb al-nuqūl yang digagas oleh Darwazah ini melihat fenomena kesejarahan tempat diturunkannya ayat al-Qurān. Karena Nabi mendapatkan wahyu pertama kali di kota Mekah, maka surat yang dikumpulkan atau ditafsirkan terlebih dahulu adalah surat-surat yang dikategorikan Makkiyah. Surat yang turunnya setelah hijrahnya Nabi ke Madinah

${ }^{14}$ Darwazah, Tafsir al-Hadith, Vol. 2, 96. 
dikategorikan sebagai surat Madaniyah. Darwazah sependapat dengan al-Suyūṭi dalam kitabnya, al-Itqān, yang menguraikan urutan turunnya surat sesuai dengan tempat kejadian. Terkadang ada surat yang turun di Mekah tetapi menggunakan ciri-ciri Madaniyah. Begitupun sebaliknya, ada surat yang turun di Madinah tetapi digolongkan ke surat Makkiyah. Namun demikian, Darwazah tidak lantas bisa dikatakan tidak setuju dengan tartīb al-nuzūl yang telah dirancang oleh Noldeke, Jỉbirī, dan lainnya. Hal tersebut hanya mengikuti Muhammad Ogly yang membuat sistematika urutan tartïb al-nuгül di bawah organisasi yang berbasis keilmuan dan ketertiban. $^{15}$

Darwazah tidak sekadar meletakkan tartīb nu₹ūili pada penafsirannya, tetapi juga menyingkap secara mendalam kisah dan cerita diturunkannya al-Qur'ān. Dalam pengantar kitab Tafsìr alHadith, ia mengatakan "bahwa hal yang teristimewa dari penafsiran al-Qur'ān adalah tidak hanya dijadikan sebagai teks bacaan saja, melainkan juga sebagai ilmu yang terselubung dalam ayat itu sendiri. Sedikit banyak, penafsiran al-Qur'ān memberikan kontribusi besar terhadap kesucian al-Qur'ān". ${ }^{16}$

Penafsiran semacam ini menuai cukup banyak kontroversi. Pertanyaan mendasar yang kerap timbul: bolehkan menafsirkan alQur'ān dengan sistematika tartïb nuгūl? Darwazah berpendapat, sebagaimana juga yang dikatakan oleh al-Suyūṭ̂ dalam al-Itqān fi Ulüm al-Qur'àn, bahwa metode penafsiran yang dinisbatkan pada bentuk asbāb al-nu₹ūl adalah sah-sah saja, selama tidak dijadikan acuan untuk bacaan-bacaan sebagaimana rasm 'Uthmānī yang sudah menjadi mushaf mutawätir, di mana al-Qur'ān dikumpulkan melalui orang-orang yang punya catatan dan kuat hafalannya, seperti Ubay b. Ka'b, 'Al̄̄ b. Abī Ṭālib, Zayd b. Thābit. ${ }^{17}$

Dalam metodologi ini, tampak aneh ketika Darwazah memosisikan al-Fātiḥah pada urutan pertama atau sebagai permulaan penafsirannya. Padahal, sebagaimana mafhum, bahwa

15 Darwazah, Tafsir al-Hadith, Vol. 10; Lihat juga Taufik Adnan Amal, Rekonstruksi Sejarah Al-Qur'an (Tangerang: Pustaka Alvabet, 2005), 210.

${ }^{16}$ Edi Komarudin et al., "Tafsir Qur'an Berbahasa Nusantara (Studi Historis terhadap Tafsir Berbahasa Sunda, Jawa, dan Aceh)", Al-Tsaqafa: Jurnal Ilmiah Peradaban Islam, Vol. 15, No. 2 (2018), 181-196.

17 Jalāl al-Dīn al-Suyūtịi, al-Itqān fì 'Ulùm al-Qur'ān, Vol. I (Beirut: al-Risālah, 2008), 310. 
surat yang turun pertama kali adalah al-'Alaq [96]: 1-5. Terkait hal tersebut, dalam pengantarnya, Darwazah menyampaikan bahwa alFātihah merupakan surat yang pertamakali turun. ${ }^{18}$ Penafsiran ini disandarkan pada hadīth yang diriwayatkan oleh Bayhaqī dan alWāhidī dari Shurḥbīl, dari Nabi Muḥammad: "Sesungguhnya alFātiḥah adalah surat yang pertama diturunkan dalam al-Qur'ān". Lebih lanjut, ia mengatakan bahwa surat al-Fātiḥah merupakan surat pembuka dalam al-Qur'ān. Tidak berhenti di situ, al-Fātiḥah juga dibaca dan menjadi rukun dalam salat lima waktu.

Darwazah menjelaskan metode penafsirannya secara jelas dan konkret sebagai berikut: ${ }^{19}$

1. Bentuk penafsirannya universal dan menyeluruh dengan memaparkan satu ayat atau beberapa ayat yang ada kaitannya dengan surat yang hendak ditafsirkannya.

2. Menjelaskan kalimat yang dianggap musykil sekadarnya saja untuk menghindari ketidakjelasan makna tertentu tanpa mendetailkan aspek kebahasaan.

3. Menjelaskan dengan global kalimat yang dijadikan objek penafsirannya.

4. Memaparkan aspek munāsabah ayat untuk memperoleh maksud dari ayat tersebut diturunkan.

5. Menghimpun ayat-ayat yang dimulai dari pen-sharíah-an hukum, akhlak, sosial-budaya, hingga kaitannya dengan rübìyah (kebatinan).

6. Menjelaskan tentang sirah nabawi (perjalanan hidup Nabi) agar memperoleh makna dari dakwah yang dikembangkannya.

7. Memaparkan jumlah-jumlah wasäìl yang kuat dari maksud kebahasaan.

8. Memperhatikan ayat yang memiliki kaitan erat dengan surat.

9. Membantu lafaz-lafaz al-Qur'ān dalam memperoleh maksud penafsiran.

10. Mengulang atau memperpanjang dalam menafsirkan al-Qur'ān.

11. Menggunakan gaya bahasa yang dekat untuk memperoleh penafsiran yang menyeluruh.

\footnotetext{
${ }_{18}$ Darwazah, Tafsir al-Hadith, Vol. 2, 130.

19 Metode ini oleh Izzat Darwazah juga dipaparkan dalam kitab al-Qur'an alMajid. Kitab tersebut merupakan ringkasan dari pemikirannya dalam bidang ilmu al-Qur'ān. Ibid., Vol. 10, 7.
} 
12. Menjelaskan kalimat-kalimat tematik dengan gamblang dan komprehensif.

Metode di atas merupakan metode Darwazah dalam menafsirkan al-Qur'ān. Namun demikian, ia tidak mengesampingkan adanya syarat dan kaidah-kaidah penafsiran seperti mubkammutashäbih, mutlaq-muqayyad, dan lain sebagainya.

Metode Darwazah tersebut berusaha menyingkap pesan yang ada dalam al-Qur'ān dengan menyeluruh. Melihat kejadian-kejadian yang mengiringi ayat atau surat pertama yang diturunkan kepada Nabi Muhammad dapat membantu memahami maksud dan tujuan ayat atau surat tersebut. Tampak sekali kecenderungan demi kecenderungan yang melekat pada penafsirannya merupakan penafsiran yang berbasis adabi ijtima $\bar{a} \hat{\imath}$ (sosio-kultural). Darwazah menampilkan penafsiran ayat sesuai konteks diturunkannya dan mengaitkan kejadian tersebut pada masa Darwazah hidup. Sebagai contoh konkret, dalam menafsirkan surat al-Kāfirūn, hal pertama yang ia lakukan adalah menjelaskan secara global dan memberikan pesan terlebih dahulu terkait surat tersebut sebelum kemudian menafsirkannya. ${ }^{20}$

\section{Perspektif Darwazah tentang Makna Kafir}

Proses pemaknaan kafir dalam pandangan Darwazah yang spesifik terlihat dalam penafsiran surat al-Kāfirūn. Dalam Tafsīr alHadīth, Darwazah memulai penafsiran dengan menyebutkan posisi al-Kāfirūn. Pertama, keunggulan al-Kāfirūn dibandingkan surat yang lain. Kedua, konteks surat al-Kāfirūn diturunkan pada masyarakat Mekah atau umat Islam di awal penyebarannya. Ketiga, sikap yang harus ditunjukkan umat Islam akibat perubahan kondisi sosial yang ada (proses peralihan masyarakat Islam dari Mekah ke Madinah).$^{21}$

Perihal posisi keutamaan al-Kāfirūn, Darwazah mengutip hadīth yang diriwayatkan oleh Tirmidhī dari Anas yang menyebutkan bahwa Nabi Muhammad bersabda: "Barang siapa yang membaca idha zulzilat, maka seakan-akan ia membaca separuh dari al-Qur'ān; barang siapa yang membaca qul yā ayyub-a al-käfirün,

\footnotetext{
20 Aksin Wijaya, Sejarah Kenabian dalam Perspektif Tafsir Nuzuli Muhammad Izzat Darwazah (Bandung: Mizan, 2012), 54.

${ }^{21}$ Muhammad Husain Haikal, Sejarah Hidup Muhammad (Bogor: Pustaka Litera Antar Nusa, 2008), 230.
} 
maka seolah-olah ia membaca seperempat dari al-Qur'ān; dan barang siapa yang membaca surat al-Ikhlās,, maka pahalanya sebanding dengan membaca sepertiga dari al-Qur'ān". 22 Setelah menjelaskan hal tersebut, kemudian Darwazah memaparkan surat al-Kāfirūn secara lengkap untuk kemudian dilakukan penafsiran sesuai dengan metode yang ia geluti sebagai seorang penafsir alQur'ān yang suci.

Respons Darwazah tentang al-Kāfirūn dinyatakan dengan asumsi bahwa surat atau ayat tersebut hadir agar Nabi Muhammad mulai melakukan dakwah secara terang-terangan kepada masyarakat kafir Quraisy. Darwazah menyandarkan pendapatnya pada tafsir al-Ṭabarī dan Ibn Kathīr yang meyakini bahwa alKāfirūn turun untuk memberikan perbedaan yang mencolok bahwa Tuhan yang disembah oleh orang Mekah tidaklah sama dengan apa yang diyakini dan disembah oleh orang Islam. Pada intinya, al-Kāfirūn adalah ìlān (pengumuman) dari Allah kepada masyarakat Mekah untuk menyembah yang ingin disembah (walaupun itu salah dalam pandangan Islam dan akan mendapatkan azab dari Allah), dan orang Islam akan menyembah apa yang diyakini dalam ajaran Islam itu sendiri. ${ }^{23}$

Dari sisi munāsabah antarayat dalam al-Qur'ān, Darwazah membingkai pemikiran tentang surat al-Kāfirun dengan surat alNaml [27]: 91-92, al-Anbiyā' [21]: 108-111, Yūnus [10]: 108, al-Hijir [15]: 94, al-Naḥl [16]: 127, al-Muzzammil [73]: 10, al-Ghāshiyah [88]: 21-22, al-Baqarah [2]: 190, 193, 256, dan al-Nisā̄ [4]: 90. ${ }^{24}$ Surat-surat ini, dalam pandangan penulis sejatinya sudah memiliki perbedaan konteks dan lokus surat atau ayat itu diturunkan. Oleh karena itu, terkait sikap orang Islam terhadap orang kafir, bagi Darwazah, berbeda dari kandungan umum surat al-Kāfirūn itu sendiri.

Darwazah menjelaskan makna kafir sesuai konteks bangsa Arab saat itu, yang sebenarnya mengetahui dan meyakini bahwa Allah adalah Tuhan yang wajib disembah. Akan tetapi, mereka acuh terhadap hal itu, sehingga mengganggap berhala atau patungpatung yang selama ini disembah adalah Tuhan yang sebenarnya.

\footnotetext{
22 Darwazah, Tafsir al-Hadith, Vol. 2, 20.

${ }^{23}$ Ibid., Vol. 10, 20.

${ }^{24}$ Ibid., 28-29.
} 
Hal ini terdapat dalam surat al-Zukhruf [43]: 87 dan surat Luqmān [31]: 25:

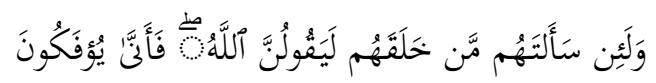

"Dan sungguh jika kamu bertanya kepada mereka: 'Siapakah yang menciptakan mereka?', niscaya mereka menjawab: 'Allah', maka bagaimanakah mereka dapat dipalingkan (dari menyembah Allah)?”.

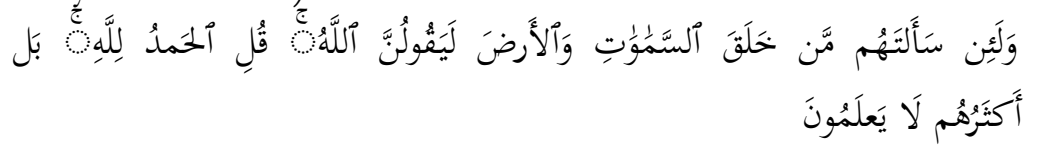

"Dan sesungguhnya jika kamu tanyakan kepada mereka: 'Siapakah yang menciptakan langit dan bumi?' Tentu mereka akan menjawab: 'Allah'. Katakanlah: 'Segala puji bagi Allah'; tetapi kebanyakan mereka tidak mengetahui".

Penggambaran tentang kondisi orang kafir Arab yang religius menjadi simbol bahwa mereka percaya terhadap Allah, tetapi tidak masuk Islam; mereka mengingkari serta menyekutukan-Nya. Mereka menjadikan patung-patung sesembahan dan menyakini bahwa malaikat merupakan banät Alläh (anak Allah). Oleh karena itu, Darwazah bersepakat pada para mufassir sebelumnya yang menyimpulkan bahwa konteks ayat yang turunnya di Mekah pada masa periode awal menjadi menunjukkan bahwa membunuh dan mencela orang-orang kafir adalah hak dan wajib. Tidak hanya itu, apapun yang berkaitan dengan mereka menjadi halal untuk dirampas dan dijadikan harta rampasan (ghanimah). ${ }^{25}$

Perubahan penafsiran tentang kata kafir kemudian terjadi pascahijrah Nabi Muhammad dari Mekah ke Madinah. Bagi Darwazah, ada perbedaan kondisi sosial di antara dua kota tersebut. Di Madinah, Nabi diperlakukan dengan sangat ramah tanpa adanya pertumpahan darah. Orang Nasrani, meski berbeda keyakinan dan peribadatannya, menyambut hangat kedatangan Rasul. Dengan keadaan yang seperti itu, firman yang Allah yang kemudian diturunkan kepada Nabi lebih bersifat penghormatan terhadap agama lain. Hal ini termaktub dalam al-Baqarah [2]: 256 berikut:

\footnotetext{
${ }^{25}$ Lihat penafsiran Yūnus [10]: 108, al-Hijr [15]: 94, al-Hajj [22]: 38-40, dan lainlain.
} 


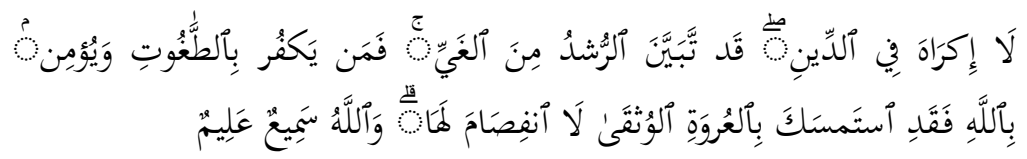

"Tidak ada paksaan untuk (memasuki) agama (Islam); sesungguhnya telah jelas jalan yang benar dari pada jalan yang sesat. Karena itu, barang siapa yang ingkar kepada Ṭaghut dan beriman kepada Allah, maka sesungguhnya ia telah berpegang kepada buhul tali yang amat kuat yang tidak akan putus. Dan Allah Maha Mendengar lagi Maha Mengetahui”.

Darwazah menafsirkan ayat di atas sebagai bentuk toleransi terhadap agama lain. Menganut agama atau kepercayaan yang berbeda tidak berarti harus saling membunuh antara yang satu dengan yang lainnya. Tidak diperkenankan adanya bentrok antara Muslim dengan orang kafir saat itu, hingga kemudian muncul sebuah perjanjian untuk berdamai dan hidup berdampingan antara Muslim dan kafir. Menurut Darwazah, proses turunnya surat alKāfirūn belum selesai. Pemaknaan utuh dari teks-teks yang ada belumlah terealisasikan, karena saat itu Rasul belum hijrah dan kondisi kafir Arab sangat terpuruk dalam hal peradaban. Fakta bahwa mereka masih percaya pada berhala yang berdiri tegak dan tidak mau menerima kebenaran atau bahkan tertutup dari kebenaran merupakan cerminan dari kekafiran mereka. Sehingga misi kebenaran yang dibawa Rasul tidak sekadar didakwahkan secara lisan, tetapi juga perbuatan dengan cara memerangi dan membunuh mereka serta mengambil hartanya.

Berdasarkan berbagai pandangan di atas, Darwazah seakan ingin menjelaskan bahwa, makna kata kafir sebagai 'musuh' umat Islam yang diturnkan pertama kali pada ayat atau surat tertentu berada pada kondisi yang belum sempurna. Tidak heran, jika di Mekah orang Islam boleh membunuh kafir Arab sampai ia masuk Islam, yang kemudian hal ini tidak berlaku ketika Nabi Muhammad mendirikan negara Madinah dan menaklukkan kota Mekah. ${ }^{26}$ Jadi, dalam penafsiran ayat di atas, Darwazah merekomendasikan untuk mengingat sejarah kenabian berdasarkan kondisi Arab Mekah maupun Madinah.

Menurut Darwazah, term kafir memiliki posisi yang berbeda dalam satu ruang ke ruang lainnya. Term tersebut secara sosiologis

${ }^{26}$ Darwazah, Tafsir al-Hadith, Vol. 10, 31. 
cenderung intoleran dan antipluralisme terhadap yang lain yang berbeda. Tidak hanya tidak bisa menghormati, tetapi lebih dari itu, term tersebut bahkan sering dijadikan ejekan untuk menjatuhkan mental orang kafir itu sendiri. Sedangkan, term non-Muslim, yaitu term lain yang secara leksikologis memiliki makna sama dengan kafir, memiliki artikulasi yang berbeda. Non-Muslim menunjuk pada Abl al-Kitäb (Yahudi dan Nasrani) dan setiap mereka yang berbeda keyakinan dengan umat Muslim. Non-Muslim yang hidup di tengah masyarakat, sejauh tidak mengganggu ketenteraman dan ikut menjaga keamanan dan perdamaian, maka ia dilindungi dan tidak halal darahnya. Tidak ada alasan bagi umat Muslim untuk tidak berbuat baik dan menjalin hubungan baik antarsesama manusia.

Inilah yang kemudian oleh Darwazah disebut sebagai jänib alMuslimin, ghayr al-Muslimin, dan kuffär (bentuk jamak dari käfir). Dalam hal keyakinan dan ibadah, ketiga term tersebut adalah sama, yaitu menyembah selain Allah. Akan tetapi, ada sedikit perbedaan dari kata ghayr al-Muslimin dan kuffär. Para ulama menafsirkan kuffär (orang-orang kafir) wajib untuk dibunuh dan tidak ada dispensasi sampai mereka masuk Islam, melakukan salat, dan menunaikan zakat. Hal tersebut dikarenakan keyakinan dan tingkah laku mereka sangat bertentangan dengan Islam. Dalam al-Tawbah [9]: 1-5:

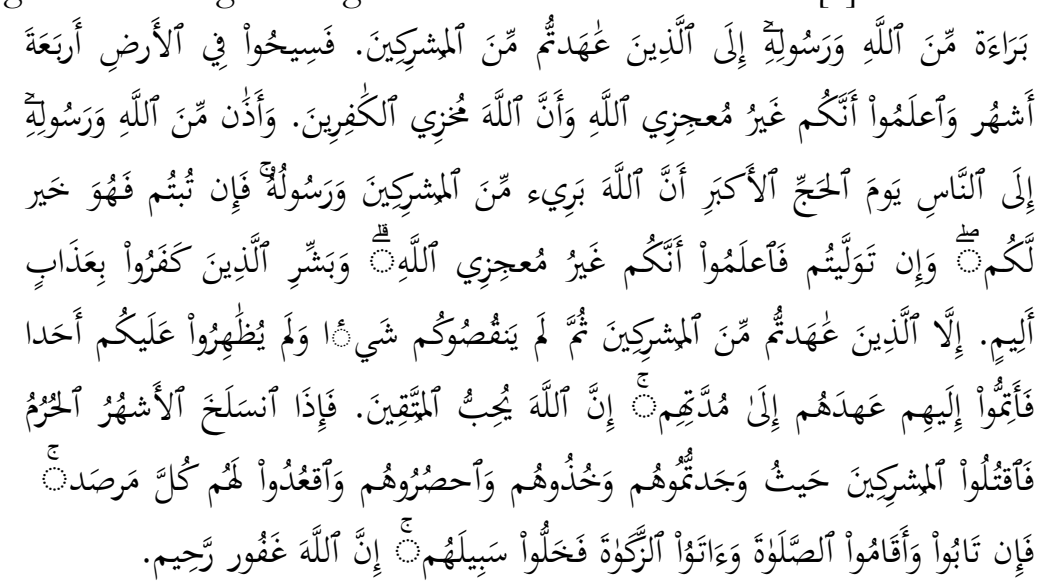

"(Inilah pernyataan) pemutusan hubungan dari Allah dan Rasul-Nya (yang dihadapkan) kepada orang-orang musyrikin yang kamu (kaum Muslimin) telah mengadakan perjanjian (dengan mereka). Maka berjalanlah kamu (kaum musyrikin) di muka bumi selama empat bulan dan ketahuilah bahwa 
sesungguhnya kamu tidak akan dapat melemahkan Allah, dan sesungguhnya Allah menghinakan orang-orang kafir. Dan (inilah) suatu permakluman dari pada Allah dan Rasul-Nya kepada umat manusia pada hari haji akbar bahwa sesungguhnya Allah dan Rasul-Nya berlepas diri dari orangorang musyrikin. Kemudian jika kamu (kaum musyrikin) bertaubat, maka itu lebih baik bagimu; dan jika kamu berpaling, maka ketahuilah bahwa sesungguhnya kamu tidak dapat melemahkan Allah. Dan beritakanlah kepada orangorang kafir (bahwa mereka akan mendapat) siksa yang pedih. Kecuali orang-orang musyrikin yang kamu telah mengadakan perjanjian (dengan mereka) dan mereka tidak mengurangi sesuatu pun (dari isi perjanjianmu) dan tidak (pula) mereka membantu seseorang yang memusuhi kamu, maka terhadap mereka itu penuhilah janjinya sampai batas waktunya. Sesungguhnya Allah menyukai orang-orang yang bertakwa. Apabila sudah habis bulan-bulan Harām itu, maka bunuhlah orang-orang musyrikin itu di mana saja kamu jumpai mereka, dan tangkaplah mereka. Kepunglah mereka dan intailah di tempat pengintaian. Jika mereka bertaubat dan mendirikan salat dan menunaikan zakat, maka berilah kebebasan kepada mereka untuk berjalan. Sesungguhnya Allah Maha Pengampun lagi maha Penyayang".

Ayat di atas merupakan ayat naskh dari al-Baqarah [2]: 256, di mana hukum membunuh orang kafir tidak dapat diberlakukan. Para mufassir berpendapat bahwa pe-naskh-an ini disandarkan pada orang Arab yang musyrik saat itu, karena mereka secara terang-terangan menolak Islam.

Setidaknya inilah pandangan Darwazah terkait pemaknaan kafir di dalam al-Qur'ān. Hal yang mungkin perlu digarisbawahi pada proses penafsiran ini ialah Darwazah tidak menanggalkan pandangan-pandangan kelompok mufassir terdahulu untuk menemukan pemaknaan yang koheren; ia tidak hanya menggunakan paradigma nuгūli sebatas untuk mencari konteks, melainkan juga pergeseran teks-teks sekaligus menggali bagaimana ayat-ayat yang memiliki satu tema di dalam al-Qur'ān menjelaskan posisi kafir di era Nabi Muhammad dan alasan-alasan ayat itu diturunkan pada masa tersebut. Dengan demikian, Darwazah sebenarnya juga tidak berdiri sendiri untuk menyatakan bahwa ada pergeseran 
pemahaman tentang konsep kafir yang terjadi pascawafatnya Nabi Muhammad.

\section{Kontekstualisasi Pemikiran Darwazah tentang Makna Kafir}

Paradigma sosio-linguistik digunakan sebagai pendekatan dalam melakukan analisis tentang pemikiran Darwazah. Paradigma sosiolinguistik merupakan kajian kebahasaan yang ditekankan pada para penuturnya. ${ }^{27}$ Dalam kajian al-Qur'ān, Faisol Fatawi mengatakan bahwa al-Qur'ān mengubah praktik kebahasaan yang ada di Arab saat itu. Secara linguistik, hal tesebut bisa dimaknai bahwa alQur'ān memiliki dialektika yang berasal dan tidak bersumber dari tradisi orang-orang Arab sebelumnya. ${ }^{28}$ Secara generik, Ngalim mengatakan sosiolinguistik sebagaimana berikut:

...cabang kajian linguistik membahas hubungan antara bahasa dengan masyarakat, yang bertujuan untuk lebih memahami adanya berbagai variasi struktur bahasa dan fungsinya dalam komunikasi. Misalnya: bagaimana ciri linguistik menyajikan karakterisasi stratum masyarakat khusus. Misalnya, stratum masyarakat khusus, di Jawa Tengah, yakni di Surakarta dan Yogyakarta, yang menunjukkan adanya ciri-ciri tertentu. ${ }^{29}$

Berdasarkan definisi di atas, secara sederhana, yang dimaksud dengan sosiolingustik sebagai kajian kebahasaan adalah sebuah disiplin yang berusaha mengkontekstualisasikan eksistensi bahasa pada komunitas tertentu, pada ruang (space) yang interaktif, dan berusaha menjelaskan bagaimana perkembangan memainkan peranannya untuk mengubah pemakaian bahasa itu sendiri. Selain itu, penulis pun memiliki asumsi bahwa apa yang hendak dilakukan oleh Darwazah dengan menggunakan metode nu₹üit dalam menafsirkan al-Qur'ān ialah untuk membangun kontekstualisasi penggunaan bahasa al-Qur'ān. Bagi Darwazah, wahyu yang kemudian berwujud menjadi teks kebahasaan tidak lahir di ruang yang kosong, justru ia adalah hasil dari pelbagai respons yang ada dalam dinamika dan kondisi sosialnya.

\footnotetext{
27 Akhmad Haryono, "Perubahan dan Perkembangan Bahasa: Tinjauan Historis dan Sosiolinguistik", Linguistika, Vol. 18 (2011), 9.

28 M. Faisol Fatawi, Tafsir Sosiolinguistik: Memahami Huruf Muqata'ah dalam AlQur'an (Malang: UIN Malang Press, 2009), 67.

29 Abdul Ngalim, "Kesantunan Berbahasa dalam Perspektif Sosiolinguistik", Prosiding Seminar Nasional Pengkajian Bahasa Unibersitas Muhammadiyah Surakarta (2013), 21.
} 
Saat menafsirkan surat al-Kāfirūn, Darwazah tidak meletakkan kata kafir sekadar pada nuansa kebahasaan masyarakat Mekah. Lebih dari itu, ia melakukan elaborasi dengan berbagai konteks dan kondisi sosial, baik itu di kala Nabi Muhammad masih berkeinginan untuk memerdekakan Mekah, atau saat sesudah berhijrah ke Madinah. Menurut Darwazah, ayat-ayat Madaniyah merupakan wujud perubahan sosial, terutama jika dikaitkan dengan penggunaan kosa kata kafir. Ada dimensi kebebasan beragama, toleransi terhadap segala perbedaan keyakinan, serta penjunjungan hak dan kewajiban bagi setiap pemeluk agama lain sebagai warga negara (citizenship). ${ }^{30}$

Darwazah memainkan kondisi sosial dalam menafsirkan alKāfirūn. Secara metodik, Imroati Kamilah menyandingkan Darwazah dengan para mufassir kontemporer yang menganggap al-Qur'ān (dari sisi kebahasaan) merupakan bentuk dialektika dari budaya Arab, bukan sebatas bentukan yang disisipkan melalui wahyu Tuhan. Ia pun mengkategorikan pemikiran Darwazah ke dalam paradigma sosiohistoris dalam kajian al-Qur'ān. Kesimpulan tersebut didapat setelah ia menelaah secara seksama penafsiran Darwazah tentang surat al-Raḥmān. ${ }^{31}$ Sementara itu, Rindom Harahap berpendapat bahwa Darwazah menempatkan nilai-nilai historis begitu dominan dalam upaya menghasilkan produk tafsirnya, khususnya pada konteks kajian gender di dalam alQur'ān. ${ }^{32}$ Jadi, apa yang diletakkan Darwazah untuk "melebarkan" makna dan sikap keagamaan kepada seorang kafir dikontekstualisasikan pada dua sisi tersebut, yakni lokasi dan nuansa kebahasaan itu sendiri.

Pada perkembangannya, pemikiran Darwazah berimplikasi pada penyebutan kafir di Indonesia. Akankah pandangan Darwazah dapat disemai untuk dijadikan fondasi berpikir, bahwa sejatinya kota kata kafir yang abadi di dalam al-Qur'ān sudah kehilangan konteks sosiologisnya di Indonesia? Untuk menjawab

\footnotetext{
30 Mengenai konteks dan konsepsi terkait Makkiyah dan Madaniah di era Nabi Muhammad, bisa dilihat pada Dzikri Nirwana, "Konsep Makkiyah dan Madaniyah dalam Studi Hadith (Menggagas Pemetaan Kronologis Hadith Nabawi)", Islamica: Jurnal Studi Keislaman, Vol. 3, No. 1 (2008), 107-118.

31 Imroati Karmillah, "Peranan Konteks Sosio-Historis dalam Penafsiran Muhammad Izzat Darwazah”, Maghza: Jurnal Ilmu Al-Qur'an dan Tafsir, Vol. 2, No. 1 (2018), 43-54.

32 Harahap, "Penafsiran Ayat-ayat Gender", 14.
} 
hal tersebut, penting untuk meminjam penafsiran salah seorang ulama Indonesia, M. Quraish Shihab, terkait konsep kafir seperti berikut ini: ${ }^{33}$ Pertama, mereka yang enggan untuk menerima keesaan Tuhan. Kedua, enggan bersyukur pada nikmat yang diberikan Tuhan. Ketiga, menghalangi atau menutup dirinya dari jalan Tuhan. Keempat, beriman tapi tidak menjalankan kewajiban yang diberikan Tuhan. Kelima, menjadikan agama sebagai permainan.

Shihab mengatakan bahwa terminologi kafir tidak dapat serta merta disematkan sesuai karakteristik Qur'ānī di atas, karena alasan dan kondisi sosial tertentu. Ia mengatakan bahwa pascawafatnya Rasulullah, penyebutan kata kafir tidak lagi digunakan kepada orang selain Islam saja, melainkan juga pada sesama umat Islam yang berbeda pandangan; kelompok Islam tertentu mengkafirkan kelompok Islam lain melandaskan pada al-Qur'ān dan kriteria yang sempit. Shihab menyatakan bahwa sejatinya penyebutan kafir kepada orang lain memiliki implikasi hukum. Ia mengatakan siapapun yang menuduh seseorang sebagai kafir, dan tidak bisa membuktikannya, maka ia sendirilah yang tergolong kafir. ${ }^{34}$ Sementara itu, menurut Cawidu, konsep kufr memiliki tingkatan, seperti halnya shirk. Konsep tersebut ia kembangkan terkait dengan klaim kufr riddah yang secara institusional menyebabkan seseorang diklaim keluar dari Islam. Setelah mengutip pendapat beberapa ulama, ia membagi pengertian kufr ke dalam dua bagian utama. Pertama, kekafiran yang menyebabkan pelakunya tidak lagi berhak disebut Muslim. Termasuk dalam kategori ini adalah jenis kufr shirk, kufr inkär, kufr jubd, kufr nifäq, dan kufr riddah. Kedua, mencakup semua perbuatan maksiat, yang secara umum dapat disebut kufr nikmat. Pelaku dari jenis kufr yang kedua ini, menurutnya, tidaklah keluar dari Islam, meskipun ia menjalani hukuman Tuhan. ${ }^{35}$

Pembagian Cawidu ini menarik, apalagi bila dikaitkan dengan implikasi hukumnya. Dalam literatur fiqh, seperti juga dikutip Cawidu, individu yang diklaim sebagai murtad (jenis kufr yang

\footnotetext{
${ }^{3}$ Muhammad Nabiel Akbar, "Makna Kafir dalam Tafsir Al-Mishbah Karya M. Quraish Shihab" (Skripsi--Universitas Muhammadiyah Surakarta, 2018), 21.

34 Lihat wawancara dengan M. Quraish Shihab pada program "Shihab \& Shihab", Narasi TV, https://youtu.be/E-pAlfBDzos. Diakses pada 22 November 2019.

35 Harifuddin Cawidu, Konsep Kufr dalam al-Qur'an: Suatu Kajian Teologis dengan Pendekatan Tafsir Tematik (Jakarta: PT Bulan Bintang, 1991), 160-161.
} 
pertama), maka darahnya dihalalkan, harta bendanya disita negara, mayatnya tidak dimandikan dan tidak dikuburkan di pekuburan Islam. ${ }^{36}$ Sebagaimana mafhum, sanksi hukum tersebut tidak berlaku bagi jenis kelompok kufr yang kedua (non-riddah); tentang mengapa jenis kufr yang kedua tersebut tidak mempunyai sanksi hukum yang berat dan bersifat sosial sebagaimana yang pertama, sementara ia juga mempunyai akibat buruk dalam sistem sosial kemasyarakatan yang bisa merugikan banyak orang; sebagaimana dasar dirumuskannya sebuah produk hukum adalah penghentian kejahatan, maka tiadanya penentangan yang tegas dan keras terhadap penentang moral agama tentu sangat sulit untuk diterima, sebab jenis kufr yang terakhir ini justru mempunyai implikasi sosial yng tidak ringan dalam kehidupan kemasyarakatan secara umum. Berdasarkan beberapa persoalan tersebut, maka kajian atas term kufr yang dilakukan oleh Cawidu masih terbilang abstrak, karena ia tidak menggunakan hermeneutika sosial dalam kajiannya. ${ }^{37}$

Kelompok otoritas keagamaan seperti Nahdlatul Ulama (NU) mulai mereduksi makna kafir dalam al-Qur'ān sesuai dengan kondisi dan paradigma sosiologis yang berkembang. Hasil pembahasan NU pada Munas Alim Ulama 2019 menyatakan bahwa kata kafir dalam konteks sosial sudah tidak dapat digunakan lagi. Pembahasaan kafir hanya dapat diletakkan pada sisi dan aspek teologis, sebab ia menyangkut sisi dogmatis yang disematkan di dalam al-Qur'ān. K.H. Mahbub Maafi, salah satu perserta baḥth almasāil mawdū'iyah pada Munas tersebut mengatakan:

Dalam konteks akidah, ya tetap seperti itu. Dalam soal waris dan soal lain, ya tetap. Dalam konteks keyakinan, ya mereka tetap kafir dengan segala konsekuensinya itu. Ini fakta yang nggak bisa dipungkiri. Jadi mereka berdiri setara. Dalam konteks bernegara, ya mereka adalah warga negara yang memiliki hak dan kewajiban yang sama sebagaimana warga negara lainnya. ${ }^{38}$

Berdasarkan pandangan Darwazah dan konteks kebahasaan yang ada di Indonesia, dapat disimpulkan beberapa hal berikut. Pertama, konteks penyebutan kafir memiliki dua dimensi penting

\footnotetext{
${ }^{36}$ Abū Bakr Jābir al-Jazā’irī, Minhāj al-Muslim (Beirut: Dār al-Fikr, 1976), 535.

37 Islah Gusmian, Khazanab Tafsir Indonesia: Dari Hermeneutika bingga Ideologi (Yogyakarta: LKiS Pelangi Aksara, 2013), 301-302.

38 "Ini Penjelasan atas Kontroversi Tiada Orang Kafir di Indonesia", 1 Maret 2019, https://www.nu.or.id/post/read/103208/ini-penjelasan-atas-kontroversitiada-orang-kafir-di-indonesia. Diakses pada 22 November 2019.
} 
secara historis dan sosiologis di kalangan masyarakat Arab; mereka yang memusuhi Islam di Mekah dan mereka yang tunduk di Madinah. Konteks ini, tentunya, sudah jauh dari kenyataan yang ada di beberapa negara Muslim sekalipun. Permusuhan yang terjadi di negara Muslim sudah lebih kompleks dari pada persoalan agama itu sendiri. Demikian juga yang ada di Indonesia, yang dibangun menggunakan paradigma atau ideologi kemajemukan, bukan lagi berasaskan pada narasi keislaman yang secara literal termaktub di dalam al-Qur'ān maupun Hadīth.

Kedua, di Mekah (sebelum peristiwa hijrah), penyebutan kafir lebih pada narasi persinggungan dialektis antara Islam dan kaum kafir Quraisy. Sehingga munculnya kalimat "lakum dinukum wa li-ya din" merupakan instruksi Allah kepada Nabi Muhammad untuk mengurangi permusuhan antarsesama makhluk-Nya, yang kemudian disusul ayat-ayat lain yang berdimensi berbeda setelah peristiwa hijrah. Pemaknaan kafir sebagai barä'ah (kebebasan) menjadi hal yang sangat substantif di dalam berinteraksi satu sama lainnya. Dalam bahasa yang lebih sederhana, Nabi Muhammad lebih memilih konsesi-psikologis dalam hubungannya dengan kelompok kafir dengan tujuan menghindari peperangan dan distabilitas sosial pada saat itu. Atau bisa saja dimaknai bahwa Nabi diberi keringanan oleh Tuhan untuk tidak selalu berperang melawan kelompok kafir Quraisy kala itu. Nabi diperintah untuk membiarkan mereka bertahan pada keyakinan lama. Tidak selalu memaksakan dengan alasan perintah menyebarkan agama Islam itu sendiri.

Ketiga, oleh karena kini sudah memiliki ambiguitas dalam praktik penggunaannya sehari-hari, maka secara kebahasaan penggunaan kafir tidak semudah pada saat kemunculannya pertama kali. Mukbätab (orang yang diajak bicara) oleh al-Qur'ān dengan penyebutan kafir sudah bergeser dan berganti. Maka dari itu, penyebutan kafir dalam konteks keindonesiaan tidak boleh "diseragamkan" (baik secara teologis maupun sosiologis) kepada mereka yang tidak memeluk agama Islam. Penyebutan kafir harus benar-benar disematkan kepada mereka yang ingin melawan dan memusuhi Islam dalam konteks peperangan, seperti ayat-ayat Madaniyah yang dinyatakan oleh Darwazah di atas. Demikian pula, harus diakui bahwa mencari pola interaksi-sosial dalam konteks peperangan di Indonesia sangatlah sulit ditemukan. Kendatipun 
ada, hal tersebut sudah menjadi tanggung jawab negara untuk menegakkan peraturan yang berasal dari konsensus bersama di kalangan masyarakat itu sendiri.

Keempat, secara sosiolinguistik, kata kafir seharusnya hilang dari diskursus keislaman di bawah negara demokratis seperti yang ada di Indonesia. Kafir bukanlah sebuah konsep untuk melabeli 'musuh umat Islam', kendati berkesesuaian dengan pelbagai karakter yang diperankan oleh kaum kafir Quraisy era Nabi Muhammad. jika memang diperlukan, kata kafir hanya bisa dipakai untuk menciptakan semangat melawan mereka yang merusak keamanan, stabilitas kehidupan, dan ingin merebut kedaulatan yang sudah diakui menjadi milik masyarakat Indonesia baik secara de facto dan de jure. Setidaknya, inilah gagasan yang dapat dielaborasi terkait bagaimana mengkontekstualisasikan pemikiran Darwazah, dalam kaitannya dengan bagaimana kini orang-orang di Indonesia menggunakan kata tersebut sebagai bahasa komunikasi, serta terkait bagaimana idealnya pemaknaan sekaligus penyebaran pemahaman kata kafir yang dipakai di dalam al-Qur’ān.

\section{Penutup}

Pandangan Darwazah yang menggunakan paradigma historis (tafsir nuұvili) mampu menguak bagaimana penggunaan bahasa kafir secara sosiologis di masa awal kemunculannya dan mampu mengelaborasi pelbagai macam ayat yang mengandung implikasi terhadap pemaknaan kafir tersebut.

Darwazah cukup konsisten untuk menempatkan bagaimana posisi nabi, posisi penulis tafsir yang dikutipnya sebagai rujukan pendapat, sekaligus bagaimana konteks kehidupannya dapat mempengaruhi pandangannya terhadap pemaknaan ayat al-Qur'ān. Darwazah mampu mengelaborasi semua hal itu dengan sangat baik. Secara teoretik, implikasi pandangannya dapat diterima oleh pelbagai kalangan, khususnya mereka yang hidup jauh dari era otoritas tunggal kenabian.

Interrelasi dalam teks yang diungkapkan Darwazah menjelaskan bahwa penyebutan kafir di Indonesia tidak menemukan relevansinya untuk digunakan sebagai labelling bagi orang yang berkeyakinan berbeda dengan umat Islam. Penyebutan kata kafir hanya dapat berfungsi pada sisi teologis yang menyangkut hati dan keyakinan seseorang. Kata kafir bagi umat Islam dapat dimaknai secara sangat luas, misalnya menutup diri dari nikmat Allah, 
menyanggah bahwa takdir Tuhan yang diberikan merupakan sebuah ketentuan yang harus dijalani, dan tidak harus dikontekskan kepada orang lain yang membedai keyakinan umat Islam. Jika terpaksa ada pelabelan seseorang sebagai kafir, maka harus ada pembuktian dan penjelasan kepada khalayak umum terkait apakah yang dimaksudkan adalah kafir secara teologis atau secara sosiologis.

Terlepas dari pelbagai persinggungan diskursif di atas, artikel ini menyimpulkan beberapa hal. Pertama, secara sosiologis, kata kafir di Indonesia tidak dapat digunakan sebagai model komunikasi di ruang publik. Kedua, penelitian ini dibingkai dengan menggunakan cara pandang pemikiran yang lebih moderat. Penulis sengaja tidak mengkontestasikan ulama atau pandangan kelompok Islam yang menyatakan kafir masih boleh disematkan kepada kelompok non-Muslim. Alasannya tidak lain adalah untuk menghindarkan pengkajian ini dari pengkaburan pemaknaan atau malah mengeluarkannya dari kerangka analisa sosiolinguistik. Dengan demikian, artikel ini akan lebih menemukan niai signifikansinya jika ditanggapi melalui nalar pemikiran kelompok Islam yang masih 'mengakui' keberadaan orang kafir di Indonesia.

\section{Daftar Rujukan}

Akbar, Muhammad Nabiel. "Makna Kafir dalam Tafsir Al-

Mishbah Karya M. Quraish Shihab". Skripsi--Universitas

Muhammadiyah Surakarta, 2018.

Amal, Taufik Adnan. Rekonstruksi Sejarah Al-Qur'an. Tangerang: Pustaka Alvabet, 2005.

Aṣfahānī (al), al-Rāghib. Mufradāt Alfāă al-Qửàn, Vol. 4. Damaskus: Dār Qalam, 2009.

Bāqī (al), Muḥammad Fu'ād 'Abd. Mu'jam al-Mufahras li Alfäă alQur'àn al-Karìm. Kairo: Dār Kutub al-Mișrīyah, 1364.

Cawidu, Harifuddin. Konsep Kufr dalam al-Qur'an: Suatu Kajian Teologis dengan Pendekatan Tafsir Tematik. Jakarta: PT Bulan Bintang, 1991.

Darwazah, Muhammad 'Izzah. Nash'at al-Harakah al-'Arabiyah alHadithah, Vol. 2. t.t.: Sidon, 1971.

----. Tafsir al-Hadith Tartib al-Suwar Hasb al-Nuqül, Vol. 2. Kairo: Dār al-Gharb al-Islāmī, 2000.

Fatawi, M. Faisol. Tafsir Sosiolinguistik: Memahami Huruf Muqata'ah dalam Al-Qur'an. Malang: UIN Malang Press, 2009. 
Gusmian, Islah. Khazanah Tafsir Indonesia: Dari Hermeneutika bingga Ideologi. Yogyakarta: LKiS Pelangi Aksara, 2013.

Haikal, Muhammad Husain. Sejarah Hidup Mubammad. Bogor: Pustaka Litera Antar Nusa, 2008.

Haryono, Akhmad. "Perubahan dan Perkembangan Bahasa: Tinjauan Historis dan Sosiolinguistik", Linguistika, Vol. 18, 2011.

Iyāzī, Muhammad 'Alī. Al-Mufassirūn Hayātubum wa Manbajubum. t.t.: al-Thaqāfah al-Irshād al-Islāmī, t.th.

Jalil, Mat. "Falsafah Hakikat Iman, Islam dan Kufur", Ath-Thariq: Jurnal Dakwah dan Komunikasi, Vol. 2, No. 2, 2019.

Jazā’irī (al), Abū Bakr Jābir. Minhājj al-Muslim. Beirut: Dār al-Fikr, 1976.

Karmillah, Imroati. "Peranan Konteks Sosio-historis dalam Penafsiran Muhammad Izzat Darwazah", Maghza: Jurnal Ilmu Al-Qur'an dan Tafsir, Vol. 2, No. 1, 2018

Komarudin, Edi et al. "Tafsir Qur'an Berbahasa Nusantara (Studi Historis terhadap Tafsir Berbahasa Sunda, Jawa, dan Aceh)", Al-Tsaqafa: Jurnal Ilmiah Peradaban Islam, Vol. 15, No. 2, 2018.

Mustaqim, Abdul. Dinamika Sejarah Tafsir al-Qur'an. Yogyakarta: Adab Press, 2014.

Narasi TV. "Shihab \& Shihab", https://youtu.be/E-pAlfBDzos. Diakses pada 22 November 2019.

Nasution, Harun. Teologi Islam: Aliran-aliran Sejarab Analisa Perbandingan. Jakarta: UI Press, 2011.

Ngalim, Abdul. "Kesantunan Berbahasa dalam Perspektif Sosiolinguistik", Prosiding Seminar Nasional Pengkajian Bahasa Unibersitas Muhammadiyah Surakarta, 2013.

Nirwana, Dzikri. "Konsep Makkiyah dan Madaniyah dalam Studi Hadith (Menggagas Pemetaan Kronologis Hadith Nabawi)", Islamica: Jurnal Studi Keislaman, Vol. 3, No. 1, 2008.

NU Online. "Ini Penjelasan atas Kontroversi Tiada Orang Kafir di Indonesia", 1 Maret 2019, https://www.nu.or.id/post/re ad/103208/ini-penjelasan-atas-kontroversi-tiada-orang-kafirdi-indonesia. Diakses pada 22 November 2019.

----. “Tentang Non-Muslim bukan Kafir", 2 Maret 2019, https://www.nu.or.id/post/read/103224/tentang-non-muslim -bukan-kafir. Diakses 22 November 2019. 
Suyūṭī (al), Jalāl al-Dīn. Al-Itqān fì Ulūm al-Qur'ān, Vol. I. Beirut: alRisālah, 2008.

Wijaya, Aksin. Sejarah Kenabian dalam Perspektif Tafsir Nuruli Muhammad Izzat Darwazah. Bandung: Mizan, 2012. 